\title{
Role of 5-aminolevulinic acid in the salinity stress response of the seeds and seedlings of the medicinal plant Cassia obtusifolia L.
}

\author{
Chun-Ping Zhang ${ }^{1}$, Yi-Cun Li ${ }^{2}$, Feng-Gang Yuan ${ }^{3}$, Shi-Jun Hư ${ }^{4}$, Hai-Ying Liu ${ }^{1}$ and Ping He ${ }^{1 *}$
}

\begin{abstract}
Background: Soil salinity, one of the major abiotic stresses affecting germination, crop growth, and productivity, is a common adverse environmental factor. The possibility of enhancing the salinity stress tolerance of Cassia obtusifolia L. seeds and seedlings by the exogenous application of 5-aminolevulinic acid (ALA) was investigated.

Result: To improve the salinity tolerance of seeds, ALA was applied in various concentrations $(5,10,15$, and $20 \mathrm{mg} / \mathrm{L})$. To improve the salinity tolerance of seedlings, ALA was applied in various concentrations (10, 25, 50, and $100 \mathrm{mg} / \mathrm{L})$. After $10 \mathrm{mg} / \mathrm{L}$ ALA treatment, physiological indices of seed germination (i.e., germination vigor, germination rate, germination index, and vigor index) significantly improved. At $25 \mathrm{mg} / \mathrm{L}$ ALA, there was a significant protection against salinity stress compared with non-ALA-treated seedlings. Chlorophyll content, total soluble sugars, free proline, and soluble protein contents were significantly enhanced. Increased thiobarbituric acid reactive species and membrane permeability levels were also inhibited with the ALA treatment. With the treatments of ALA, the levels of chlorophyll fluorescence parameters, i.e., the photochemical efficiency of photosystem II $\left(F_{v} / F_{m}\right)$, photochemical efficiency $\left(F_{v} / F_{m}{ }^{\prime}\right)$, PSII actual photochemical efficiency (DPSII), and photochemical quench coefficient ( $q P)$, all significantly increased. In contrast, the non-photochemical quenching coefficient (NPQ) decreased. ALA treatment also enhanced the activities of superoxide dismutase, peroxidase, and catalase in seedling leaves. The highest salinity tolerance was obtained at $25 \mathrm{mg} / \mathrm{L}$ ALA treatment.
\end{abstract}

Conclusion: The plant growth regulator ALA could be effectively used to protect C. obtusifolia seeds and seedlings from the damaging effects of salinity stress without adversely affecting plant growth.

Keywords: 5-Aminolevulinic acid; Antioxidant enzymes; Cassia obtusifolia L.; Chlorophyll; Chlorophyll fluorescence; Salinity stress; Seed germination

\section{Background}

Soil salinity has become a global problem. A large number of lands are being eroded by salt, and numerous plants are being subjected to increasing salinity stress. Soil salinity, one of the major abiotic stresses affecting germination, crop growth, and productivity, is a common adverse environmental factor. Soil salinity affects plant growth, the global geographic distribution of vegetation, and the restriction of medicinal plant yields

\footnotetext{
*Correspondence: heping196373@163.com

${ }^{1}$ School of Life Sciences, Southwest University, Key Laboratory (Ministry of

Education) of Eco-environments of Three Gorges Reservoir Region,

Chongqing Key Laboratory of Plant Ecology and Resources Research for

Three Gorges Reservoir Region, Chongqing 400715, PR China

Full list of author information is available at the end of the article
}

(Zhang et al. 2011). Under salinity stress, plants are very adversely affected by the generation of harmful oxygen species, leading to oxidative stress (Ahmad et al. 2005; Wahid et al. 2007).

Several protective mechanisms change to different extents with increased amounts of oxygen free radicals. Such mechanisms include those involving free radical and peroxide scavenging enzymes, e.g., superoxide dismutase (SOD), peroxidase (POD), and catalase (CAT) (McDonald 1999; $\mathrm{Li}$ et al. 2008). SOD is key to the regulation of the amounts of superoxide radicals and peroxides. Hydrogen peroxide $\left(\mathrm{H}_{2} \mathrm{O}_{2}\right)$ can form hydroxyl radicals via the Haber-Weiss reaction, subsequently causing lipid peroxidation. CAT and POD are implicated in the removal of $\mathrm{H}_{2} \mathrm{O}_{2}$ (Zhang et al. 2010). $\mathrm{H}_{2} \mathrm{O}_{2}$ removal via a series of 
reactions is known as the ascorbate glutathione cycle. In this cycle, ascorbate and glutathione participate in a cyclic transfer of reducing equivalents resulting in the reduction of $\mathrm{H}_{2} \mathrm{O}_{2}$ to $\mathrm{H}_{2} \mathrm{O}$ using electrons derived form nicotinamide adenine dinucleotide phosphate (Goel and Sheoran 2003). The germination vigor and rate of seed are also reduced under salt stress. Some other symptoms of salinity stress include malondialdehyde increase, protein degradation.

Chl fluorescence is widely used in analyzing photosynthetic apparatuses. Chl fluorescence is also employed to understand the mechanism of photosynthesis and the mechanism by which a range of environmental factors alter photosynthetic activity under both biotic and abiotic stresses (Sayed 2003). Fluorescence parameters have also been applied in the rapid identification of injury to leaves in the absence of visible symptoms, and in the detailed analysis of change in photosynthetic capacity (Maxwell and Johnson 2000). Therefore, Chl fluorescence may be used as a potential indicator of environmental stress and a screening method of stress-resistant plants.

5-Aminolevulinic acid (ALA) is a key precursor in the biosynthesis of all porphyrins compounds, such as Chl, heme, and phytochrome (Eiji et al. 2003). The exogenous applications of ALA regulate plant growth and development, as well as enhance Chl biosynthesis and photosynthesis, resulting in increased crop yield (Hotta et al. 1997a). In plants, ALA concentration is strictly controlled to less than $50 \mathrm{nmol \cdot g}{ }^{-1} \mathrm{FW}$ (Stobart and Ameen-Bukhari 1984). ALA undergoes enolization and further metalcatalyzed aerobic oxidation at physiological $\mathrm{pH}$ to yield superoxide radical $\left(\mathrm{O}_{2}^{-}\right)$, hydrogen peroxide $\left(\mathrm{H}_{2} \mathrm{O}_{2}\right)$, and hydroxyl radical (HO.). Accumulated $\mathrm{Chl}$ intermediates are assumed to act as photosensitizers for the formation of singlet oxygen $\left({ }^{1} \mathrm{O}_{2}\right)$, triggering photodynamic damage in ALA-treated plants (Chakrabory and Tripathy 1992). Therefore, ALA accumulation enhances the levels of reactive oxygen species (ROS), leading to oxidative stress and herbicidal activity. Herbicidal activity has been reported to increase the accumulation of several Chl intermediates, such as protochlorophyllide, protoporphyrin IX, and Mg-protoporphyrin IX, when plants are treated with exogenous ALA at relatively high concentrations $\left(5 \mathrm{mmol} \cdot \mathrm{L}^{-1}\right.$ to $\left.40 \mathrm{mmol} \cdot \mathrm{L}^{-1}\right)$. However, low ALA concentrations $\left(0.06 \mathrm{mmol} \cdot \mathrm{L}^{-1}\right.$ to $\left.0.60 \mathrm{mmol} \cdot \mathrm{L}^{-1}\right)$ appear to promote rather than damage plant growth by increasing nitrate reductase activity, increasing fixation of $\mathrm{CO}_{2}$ in light, and suppressing the release of $\mathrm{CO}_{2}$ in darkness (Hotta et al. 1997b). ALA treatments of rice, barley, potato, and garlic plants at their early growth stages promote plant growth and photosynthetic rates, resulting in significant yield enhancements. Low-concentration ALA applications are also known to enhance plant tolerance to cold (Wang et al. 2003) and salinity stresses (Nishihara et al. 2003; Zhang et al. 2006). At concentrations over $5 \mathrm{mmol} \cdot \mathrm{L}^{-1}$, herbicidal effects are exhibited (Kumar et al. 1999), suggesting the great potential of ALA as a new non-toxic endogenous substance for agricultural applications (Wang et al. 2003).

Cassia obtusifolia L. is a well known traditional Chinese medicinal plant belonging to the medically and economically important family Leguminosae (Syn. Fabaceae), subfamily Caesalpinioideae (Joshi and Kapoor 2003). The seed of the plant, called Juemingzi in China, is widely used for treating headache, dizziness, as well as red and teared eyes. In previous investigations of this plant, a number of constituents have been isolated, including anthraquinones, anthrones, flavonoids, triterpenoids, and so on. The anthraquinone derivatives, anthronic, dianthronic, and anthraquinone glycosides of Cassia are responsible for its purgative action (Anu and Rao 2001 ).

The mechanisms of ALA in promoting stress tolerance in plants need to be elucidated. The present paper provides the first evidence of the capability of ALA to protect $C$. obtusifolia seeds and seedlings against salinity stress, significantly contributing to the understanding of the ALA role in promoting salinity stress tolerance. The specific objective is to determine the optimum ALA concentration that provides the best protection against this stress.

\section{Methods \\ Chemicals}

ALA was obtained from the Korea Advanced Institute of Science and Technology (KAIST, Korea). All other chemicals were of analytical grade and obtained from Sigma Chemical (St. Louis, Missouri, U.S.A).

\section{Plant material}

C. obtusifolia seeds were obtained from Institute of Medicinal Plant Development, Chinese Academy of Medical Sciences (Beijing, P.R. China). The seeds were surface sterilized with $2 \%(\mathrm{v} / \mathrm{v})$ sodium hypochlorite solution for $10 \mathrm{~min}$, and thoroughly washed with distilled water (Korkmaz 2005). The seeds were then germinated in covered $9 \mathrm{~cm}$ Petri dishes. Based on a preliminary experiment, $100 \mathrm{mmol} \cdot \mathrm{L}^{-1} \mathrm{NaCl}$ was used in the salinity stress experiment.

\section{Seed germination treatments}

The seed germination experiment included seven treatments: (1) distilled deionized water (CK1), (2) $100 \mathrm{mmol} \cdot \mathrm{L}^{-1}$ $\mathrm{NaCl}$ (CK2), (3) $10 \mathrm{mg} \cdot \mathrm{L}^{-1}$ ALA (CK3), (4) $100 \mathrm{mmol} \cdot \mathrm{L}^{-1}$ $\mathrm{NaCl}+5 \mathrm{mg} \cdot \mathrm{L}^{-1}$ ALA (T1), (5) $100 \mathrm{mmol} \cdot \mathrm{L}^{-1} \mathrm{NaCl}+10$ $\mathrm{mg} \cdot \mathrm{L}^{-1}$ ALA (T2), (6) $100 \mathrm{mmol} \cdot \mathrm{L}^{-1} \mathrm{NaCl}+15 \mathrm{mg} \cdot \mathrm{L}^{-1}$ ALA (T3), and (7) $100 \mathrm{mmol} \cdot \mathrm{L}^{-1} \mathrm{NaCl}+20 \mathrm{mg} \cdot \mathrm{L}^{-1} \mathrm{ALA}$ (T4). Water was supplemented to the dishes every day 
and three replicates with fifty seeds per dish were used for each treatment in a light incubator under a $12 / 12 \mathrm{~h}$ photoperiod (light/dark; $450 \mu \mathrm{mol} \cdot \mathrm{m}^{-2} \cdot \mathrm{s}^{-1} ; 25 \pm 1^{\circ} \mathrm{C}$ ). The experiment was repeated three times under the same conditions $(\mathrm{n}=9)$. Radicle emergence was the criterion used to assess germination, and was recorded daily for $6 \mathrm{~d}$ until the numbers stabilized. Germinated seeds were removed from the Petri dishes. The physiological indices of seed germination were determined as follow: germination vigor $(\mathrm{GV})=A / C$, germination rate $(\mathrm{GR})=B / C$, germination index $(\mathrm{GI})=\Sigma(G t / D t)$, and vigor index $(\mathrm{VI})=\mathrm{GI} \times S$. $A$ is the total number of seeds germinated in $4 \mathrm{~d}, B$ is the total number of seeds germinated in $6 \mathrm{~d}$, and $C$ is the total seeds in the experiment. $G t$ is the germination percentage after $t$ days, and $D t$ is the days of germination. $S$ is the radicle mean and length upon the termination of germination ( $6 \mathrm{~d}$ later). The fresh weight as well as length of radicle and plumule with different treatments were measured after the germination stopped.

\section{Seedlings treatments}

Seeds without any treatment were sown in pots filled with growth medium consisting of 4:1 peat and perlite. The pots were watered and placed in a greenhouse under a $12 / 12 \mathrm{~h}$ photoperiod, $25 / 20^{\circ} \mathrm{C}$ (light/dark) temperature regime and $65 \%$ relative humidity. At the tworeal-leaf stage, seedlings were irrigated with half-strength of Hoagland nutrient solution every day. After $25 \mathrm{~d}$ of pre-culture, the seedlings were at the stage of 4 to 5 real leaves and the treatment was started. The seedling experiment included seven treatments: (1) Hoagland nutrient solution (CK1), (2) Hoagland nutrient solution $+100 \mathrm{mmol} \cdot \mathrm{L}^{-1}$ $\mathrm{NaCl}$ (CK2), (3) Hoagland nutrient solution $+25 \mathrm{mg} \cdot \mathrm{L}^{-1}$ ALA (CK3), (4) Hoagland nutrient solution $+100 \mathrm{mmol} \cdot \mathrm{L}^{-1}$ $\mathrm{NaCl}+10 \mathrm{mg} \cdot \mathrm{L}^{-1}$ ALA (T1), (5) Hoagland nutrient solution $+100 \mathrm{mmol} \cdot \mathrm{L}^{-1} \mathrm{NaCl}+25 \mathrm{mg} \cdot \mathrm{L}^{-1}$ ALA (T2), (6) Hoagland nutrient solution $+100 \mathrm{mmol} \cdot \mathrm{L}^{-1} \mathrm{NaCl}+50 \mathrm{mg} \cdot \mathrm{L}^{-1}$ ALA (T3), and (7) Hoagland nutrient solution $+100 \mathrm{mmol} \cdot \mathrm{L}^{-1}$ $\mathrm{NaCl}+100 \mathrm{mg} \cdot \mathrm{L}^{-1}$ ALA (T4). The nutrient solution was supplemented to the pots every other day, whereas the ALA was supplemented every day. The experimental design was a randomized complete block with six treatments arranged in individual pots with nine plants per treatment and three replicates each. The experiment was repeated three times under the same conditions $(n=9)$. The experiment with all treatment were executed at dusk because ALA easily decomposes in light. The seedling samples were collected for assays at the 4th, 8th, and 12th days, respectively.

\section{Chlorophyll content determination}

The contents of total Chl, Chl $a$ and $\mathrm{Chl} b$ were determined by collecting fresh leaf samples $(0.5 \mathrm{~g})$ from randomly selected 9 plants per replicate. The samples were homogenized with $5 \mathrm{ml}$ of acetone $(80 \%, \mathrm{v} / \mathrm{v})$ using a mortar and pestle before being filtered through a Whatman No.2 filter paper. The absorbance was measured using a UV-visible spectrophotometer (UV-2550, Shimadzu, Japan) at 663 and $645 \mathrm{~nm}$ (Lichtenthaler 1987).

\section{Chlorophyll fluorescence}

The Chl fluorescence of leaves was measured at room temperature $\left(25^{\circ} \mathrm{C}\right)$ using a pulse-modulated fluorometer (PAM-2500, Walz, Germany) after the leaves were dark adapted for $30 \mathrm{~min}$. The detailed experimental protocol was as followed (Genty et al. 1989). The minimal fluorescence $\left(F_{\mathrm{o}}\right)$ with all PSII reaction centers open was measured with modulated light that was sufficiently low $\left(<0.05 \mu \mathrm{mol} \cdot \mathrm{m}^{-2} \cdot \mathrm{s}^{-1}\right.$ as not to induce significant variable fluorescence. The maximal fluorescence $\left(F_{\mathrm{m}}\right)$ with all PSII reaction centers closed was determined by a $0.8 \mathrm{~s}$ saturating pulse at $8000 \mu \mathrm{mol} \cdot \mathrm{m}^{-2} \cdot \mathrm{s}^{-1}$ in dark-adapted leaves. Then, leaves were continuously illuminated with $336 \mu \mathrm{mol} \cdot \mathrm{m}^{-2} \cdot \mathrm{s}^{-1}$ white actinic light. The steady-state value of fluorescence $\left(F_{\mathrm{s}}\right)$ was thereafter recorded and a second saturating pulse at $8000 \mu \mathrm{mol} \cdot \mathrm{m}^{-2} \cdot \mathrm{s}^{-1}$ was imposed to determine the maximal fluorescence in the light-adapted state $\left(F_{\mathrm{m}}{ }^{\prime}\right) . F_{\mathrm{o}}{ }^{\prime}$ was the basal fluorescence after far-red illumination. The photosynthetic parameters were calculated using the PAMWIN Data Acquisition System (Walz, Germany) as follow: the photochemical efficiency of PSII $\left(F_{\mathrm{v}} / F_{\mathrm{m}}\right)=\left(F_{\mathrm{m}}-F_{\mathrm{o}}\right) / F_{\mathrm{m}}$, the excitation capture efficiency of open PSII reaction centers $\left(F_{\mathrm{v}}{ }^{\prime} / F_{\mathrm{m}}{ }^{\prime}\right)=$ $\left(F_{\mathrm{m}}{ }^{\prime}-F_{\mathrm{o}}{ }^{\prime}\right) / F_{\mathrm{m}}{ }^{\prime}$, and the coefficients of photochemical quenching $(q P)=\left(F_{\mathrm{m}}{ }^{\prime}-F_{\mathrm{s}}\right) /\left(F_{\mathrm{m}}{ }^{\prime}-F_{\mathrm{o}}{ }^{\prime}\right)$, coefficient of nonphotochemical quenching $(\mathrm{NPQ})=\left(F_{\mathrm{m}}-F_{\mathrm{m}}{ }^{\prime}\right) / F_{\mathrm{m}}{ }^{\prime}$, and actual photochemical efficiency of PSII $($ ФPSII $)=\left(F_{\mathrm{m}}{ }^{\prime}-F_{\mathrm{s}}\right) /$ $F_{\mathrm{m}}{ }^{\prime}$ (Demmig-Adams et al. 1996). Fluorescence measurements were performed in four-flag-leaf stage per treatment combination and all measurements were made between 8:00 to 11:00 a.m. and replicated at least six times.

\section{Membrane permeability determination}

The level of membrane permeability was represented by the relative conductivity. The electrical conductivity of leaf leachates in double distilled water was recorded at 40 and $100^{\circ} \mathrm{C}$ (Sairam 1994). Leaf samples $(0.1 \mathrm{~g})$ were cut into uniformly sized discs and placed in test tubes containing $10 \mathrm{~mL}$ of double distilled water in two sets. One set was kept at $40^{\circ} \mathrm{C}$ for $60 \mathrm{~min}$, and the other was at $100^{\circ} \mathrm{C}$ in boiling water bath for $30 \mathrm{~min}$. Their respective electric conductivities $C_{1}$ and $C_{2}$ were measured by a conductivity meter. The relative conductivity index was $\left(C_{1} / C_{2}\right) \times 100 \%$. 


\section{Determination of thiobarbituric acid (TBA)-reactive substances}

The level of lipid peroxidation was measured in terms of the content of TBA-reactive substances (TBARS) (Heath and Packer 1968). Fresh leaf samples (0.5 g) were homogenized in $10 \mathrm{~mL}$ of $0.1 \%$ trichloro-acetic acid (TCA). The homogenate was centrifuged at $15000 \times g$ for $5 \mathrm{~min}$. About $2 \mathrm{~mL}$ of aliquot of the supernatant was mixed with $4 \mathrm{~mL}$ of $0.5 \% \mathrm{TBA}$ in $20 \% \mathrm{TCA}$. The mixture was heated at $95^{\circ} \mathrm{C}$ for $30 \mathrm{~min}$, and then quickly cooled in an ice bath. After centrifugation at $10000 \times g$ for $10 \mathrm{~min}$ to remove suspended turbidity, the absorbance of the supernatant was recorded at $532 \mathrm{~nm}$. The value for nonspecific absorption at $600 \mathrm{~nm}$ was subtracted. The TBARS content was calculated using its absorption coefficient of $155 \cdot \mathrm{mmol}^{-1} \cdot \mathrm{cm}^{-1}$.

\section{Osmotic substances}

The osmotic substances measured in the experiment included total soluble sugars, free proline, and soluble protein. Total soluble sugars were estimated using anthrone reagent (Yemm and Willis 1954). Samples were extracted with $4 \mathrm{ml}$ of $80 \%$ methanol at $80^{\circ} \mathrm{C}$ for $40 \mathrm{~min}$ and were then centrifuged at $2000 \times g$ for $15 \mathrm{~min}$. The methanol supernatants of three successive centrifugations were used for the sugar analyses. About $4 \mathrm{~mL}$ of anthrone reagent was then added. The mixture was heated in a boiling water bath for $8 \mathrm{~min}$, and then cooled. Optical density of green to dark green color was read at $630 \mathrm{~nm}$.

Free proline accumulation is widely used as a parameter of salt stress tolerance (Storey and Wyn-Jones 1975). In the present study, free proline content in leaves was determined by the following method. Fresh leaf samples $(0.5 \mathrm{~g})$ were homogenized in $5 \mathrm{~mL}$ of sulfosalicylic acid (3\%) using a mortar and pestle. About $2 \mathrm{~mL}$ of the extract was placed in a test tube. About $2 \mathrm{~mL}$ each of glacial acetic acid and ninhydrin were added. The reaction mixture was boiled in a water bath at $100^{\circ} \mathrm{C}$ for $30 \mathrm{~min}$. The reaction mixture was cooled, mixed with $6 \mathrm{~mL}$ of toluene, and then transferred into a separating funnel. After thorough mixing, the chromophore containing toluene was separated, and absorbance was read at $520 \mathrm{~nm}$ against a toluene blank. The concentration of free proline was estimated by referring to a standard curve (Bates et al. 1973).

Soluble protein was extracted from $0.5 \mathrm{~g}$ of fresh leaf using $2 \mathrm{~mL}$ of $50 \mathrm{mmol} \cdot \mathrm{L}^{-1}$ sodium phosphate buffer ( $\mathrm{pH}$ 7.4). Soluble protein content was determined by the method of using bovine serum albumin (BSA) as a standard (Lowry et al. 1951).

\section{Enzyme extraction and enzymatic activity determination} Fresh leaf samples $(1.0 \mathrm{~g})$ were rapidly extracted in a pre-chilled mortar on an ice bath using $5 \mathrm{ml}$ of ice-cold
$100 \mathrm{mmol} \cdot \mathrm{L}^{-1}$ phosphate buffer (pH 7.8) containing 1.0 $\mathrm{mmol} \cdot \mathrm{L}^{-1}$ ethylenediaminetetraacetic acid and $5 \%\left(\mathrm{w} \cdot \mathrm{v}^{-1}\right)$ polyvinylpyrrolidone. After centrifugation at $12000 \times g$ for $30 \mathrm{~min}$ at $4^{\circ} \mathrm{C}$, the supernatant was used for the determination of enzymatic activities.

SOD activity was determined by first mixing $0.1 \mathrm{~mL}$ of the enzyme extract with $2.465 \mathrm{~mL}$ of $100 \mathrm{mmol} \cdot \mathrm{L}^{-1}$ phosphate buffer ( $\mathrm{pH} 7.8$ ), $75 \mu \mathrm{L}$ of $55 \mathrm{mmol} \cdot \mathrm{L}^{-1}$ methionine, $300 \mu \mathrm{L}$ of $0.75 \mathrm{mmol} \cdot \mathrm{L}^{-1}$ nitroblue tetrazolium $(\mathrm{NBT})$, and $60 \mu \mathrm{L}$ of $0.1 \mathrm{mmol} \cdot \mathrm{L}^{-1}$ riboflavin in a test tube. The test tubes containing the reaction solution were irradiated under 2 fluorescent light tubes $\left(40 \mu \mathrm{mol} \cdot \mathrm{m}^{-2} \cdot \mathrm{s}^{-1}\right)$ for $10 \mathrm{~min}$. The absorbance was measured at $560 \mathrm{~nm}$. Blanks and controls were run in the same manner but without illumination and the enzyme extract, respectively. One unit of SOD activity was defined as the amount of enzyme that inhibits $50 \%$ of NBT photo reduction (Xu et al. 2008).

POD activity was determined as follow. The reaction mixture contained $0.1 \mathrm{~mL}$ of enzyme extract, $2 \mathrm{~mL}$ of 0.1 mol sodium acetate buffer $(\mathrm{pH}=4.5)$, and $0.5 \mathrm{~mL}$ of $o$-dianisidine solution $(0.2 \%$ in methanol, freshly prepared). The reaction was initiated with the addition of $0.1 \mathrm{~mL}$ of $0.2 \mathrm{~mol} \mathrm{H}_{2} \mathrm{O}_{2}$. The change in absorbance was recorded at $470 \mathrm{~nm}$ at an interval of $15 \mathrm{~s}$ for $2 \mathrm{~min}$. One unit of POD was defined as $0.1 \Delta \mathrm{A}_{470} / \mathrm{min}$ (Kalpana and Madhava Rao 1995).

CAT activity was estimated as follow. The reaction mixture contained $0.6 \mathrm{~mL}$ enzyme extract, $0.1 \mathrm{~mL}$ of 10 mmol $\mathrm{H}_{2} \mathrm{O}_{2}$, and $2 \mathrm{~mL}$ of $30 \mathrm{mmol}$ phosphate buffer $(\mathrm{pH}=7.0)$. The absorbance was recorded at $240 \mathrm{~nm}$ immediately after enzyme extract addition at an interval of $15 \mathrm{~s}$ for $2 \mathrm{~min}$. The blank did not contain enzyme extract. One unit of CAT was defined as $0.1 \Delta A_{240} / \mathrm{min}$ (Goel and Sheoran 2003).

\section{Statistics}

Values were presented as the mean \pm standard deviation of there replicates. Statistical analyses were carried out by ANOVA. Tukey's test was used to compare the means multiple treatments. To fit the normality, percentage values were arcsine transformed prior to statistical analysis. The significance level was set at $P=0.05$.

\section{Results}

\section{Seeds germination}

ALA with different concentrations significantly affected the seed germination indices GV, GR, GI, and VI of $C$. obtusifolia seeds under salinity stress (Table 1). The indices of seeds treated with only $\mathrm{NaCl}$ (CK2) significantly differed from the control (CK1).The indices improved after the treatment of ALA (CK3, $\left.10 \mathrm{mg} \cdot \mathrm{L}^{-1}\right)$ only. On the other hand, the indices varied with increased ALA concentrations. The indices improved with different ALA concentrations (T1-T4), and treatment $\mathrm{T} 2$ raised 
Table 1 Germination vigor (GV), germination rate (GR), germination index (GI), and vigor index (VI) of C. obtusifolia seeds treated with different ALA under salinity stress ${ }^{a}$

\begin{tabular}{ccccc}
\hline Treatment & GV & GR & Gl & VI \\
\hline CK1 & $76.31 \pm 4.01 \mathrm{a}$ & $98.24 \pm 7.01 \mathrm{a}$ & $89.94 \pm 3.01 \mathrm{a}$ & $11.37 \pm 1.12 \mathrm{a}$ \\
CK2 & $52.78 \pm 7.23 \mathrm{c}$ & $71.29 \pm 7.34 \mathrm{~d}$ & $48.66 \pm 5.32 \mathrm{~d}$ & $6.38 \pm 0.83 \mathrm{~d}$ \\
CK3 & $79.96 \pm 5.49 \mathrm{a}$ & $99.12 \pm 6.69 \mathrm{a}$ & $90.15 \pm 4.98 \mathrm{a}$ & $11.52 \pm 0.98 \mathrm{a}$ \\
T1 & $60.44 \pm 6.13 \mathrm{~b}$ & $81.33 \pm 6.23 \mathrm{~b}$ & $75.36 \pm 4.13 \mathrm{~b}$ & $8.03 \pm 1.24 \mathrm{~b}$ \\
T2 & $78.28 \pm 6.15 \mathrm{a}$ & $98.16 \pm 8.19 \mathrm{a}$ & $89.07 \pm 6.15 \mathrm{a}$ & $10.86 \pm 1.39 \mathrm{a}$ \\
T3 & $65.32 \pm 6.29 \mathrm{ab}$ & $83.27 \pm 5.46 \mathrm{ab}$ & $80.42 \pm 4.08 \mathrm{ab}$ & $8.82 \pm 1.27 \mathrm{ab}$ \\
T4 & $59.68 \pm 6.23 \mathrm{~b}$ & $78.31 \pm 8.44 \mathrm{c}$ & $69.89 \pm 5.53 \mathrm{c}$ & $8.02 \pm 1.44 \mathrm{c}$ \\
\hline
\end{tabular}

${ }^{a}$ Data are the means of three independent replicates. Means \pm standard errors $(n=9)$ within each column followed by different letters are significantly different at the $P=0.05$ level.

the indices to a level that did not differ significantly from the unstressed control (CK1). The optimum ALA concentration for alleviating C. obtusifolia seed damage was $10 \mathrm{mg} \cdot \mathrm{L}^{-1}$.

\section{Seedlings growth}

The radicle length, plumule length, radicle/plumule ratio, and fresh weight of C. obtusifolia seedlings under salinity stress treated with different ALA concentrations were measured after germination was stopped. The tendencies of the radicle length, plumule length, and fresh weight with different treatments were similar (Table 2). Treatment with only $\mathrm{NaCl}$ stress (CK2) resulted in a significant decrease compared with no $\mathrm{NaCl}$ stress treatment (CK1) and reached the minimum value. However, different ALA concentrations improved the growth indices. The radicle/plumule ratio increased with all ALL treatments and treatments T2-T4 restored the parameter to values that did not differ significantly from the unstressed CK1. Under salinity stress, plumule growth was inhibited to a greater extent than radicle growth. The radicle/plumule ratio increased, possibly indicating that the different vegetative organs of seedlings adjust this ratio to ensure maximum survival and seedling growth.

\section{Chl content}

The seedling leaves of C. obtusifolia treated under $\mathrm{NaCl}$ stress $(100 \mathrm{mmol} / \mathrm{L})$ had lower $\mathrm{Chl}$ content than the control CK1 (Figure 1). Chl $a$, Chl $b$, and total Chl content (CK1, CK3) decreased with the treatment days compared with CK2. ALA applied in increasing concentrations to salinity stress expectedly enhanced the Chl content of the seedlings because ALA is a precursor in Chl biosynthesis. On the other hand, seedlings treated with increased ALA concentrations caused different enhancements in Chl content. ALA concentration increased with $25 \mathrm{mg} \cdot \mathrm{L}^{-1} \mathrm{ALA}$ (T2) resulted in improved Chl content compared with the CK2. However, $10 \mathrm{mg} / \mathrm{LALA}$ has no significant difference compared with the CK2 at 4 and 8 days, further increased ALA concentration to $50 \mathrm{mg} \cdot \mathrm{L}^{-1}$ (T3) caused a slight decrease of total Chl compared with $25 \mathrm{mg} \cdot \mathrm{L}^{-1}$ (T2), and the minimum value was reached with $100 \mathrm{mg} \cdot \mathrm{L}^{-1} \mathrm{ALA}(\mathrm{T} 4)$.

\section{Chl fluorescence}

The photochemical efficiency of PSII $\left(F_{\mathrm{v}} / F_{\mathrm{m}}\right)$, the excitation capture efficiency of open PSII reaction centers $\left(F_{\mathrm{v}}{ }^{\prime} /\right.$ $\left.F_{\mathrm{m}}{ }^{\prime}\right)$, actual photochemical efficiency of PSII (ФPSII), and coefficients of photochemical quenching $(q P)$ under $100 \mathrm{mmol} \cdot \mathrm{L}^{-1} \mathrm{NaCl}$ stress (CK2) all significantly decreased

Table 2 Radicle length, plumule length, radicle/plumule ratio, and fresh weight of $C$. obtusifolia seedlings treated with different ALA concentrations under salinity stress after germination is terminated ${ }^{\mathrm{a}}$

\begin{tabular}{ccccc}
\hline Treatment & Radicle length $(\mathbf{c m})$ & Plumule length $(\mathbf{c m})$ & Radicle/plumule ratio & Fresh weight $(\mathbf{m g})$ \\
\hline CK1 & $2.79 \pm 0.36 \mathrm{a}$ & $4.12 \pm 0.65 \mathrm{a}$ & $0.67 \pm 0.13 \mathrm{c}$ & $162.7 \pm 5.7 \mathrm{a}$ \\
CK2 & $2.33 \pm 0.25 \mathrm{c}$ & $2.51 \pm 0.68 \mathrm{~d}$ & $0.93 \pm 0.16 \mathrm{a}$ & $113.6 \pm 6.4 \mathrm{~d}$ \\
CK3 & $2.81 \pm 0.43 \mathrm{a}$ & $4.14 \pm 0.66 \mathrm{a}$ & $0.68 \pm 0.16 \mathrm{c}$ & $165.58 \pm 5.2 \mathrm{a}$ \\
T1 & $2.52 \pm 0.34 \mathrm{~b}$ & $3.56 \pm 0.75 \mathrm{~b}$ & $0.71 \pm 0.09 \mathrm{bc}$ & $140.3 \pm 3.5 \mathrm{~b}$ \\
T2 & $2.78 \pm 0.31 \mathrm{a}$ & $4.13 \pm 0.49 \mathrm{a}$ & $0.67 \pm 0.21 \mathrm{c}$ & $161.5 \pm 4.8 \mathrm{a}$ \\
T3 & $2.65 \pm 0.18 \mathrm{ab}$ & $3.74 \pm 0.66 \mathrm{ab}$ & $0.71 \pm 0.6 \mathrm{bc}$ & $148.8 \pm 3.1 \mathrm{ab}$ \\
T4 & $2.60 \pm 0.76 \mathrm{ab}$ & $3.27 \pm 0.53 \mathrm{c}$ & $0.79 \pm 0.08 \mathrm{~b}$ & $130.6 \pm 4.4 \mathrm{c}$ \\
\hline
\end{tabular}

${ }^{\mathrm{a}}$ Data are the means of three independent replicates. Means \pm standard errors $(n=9)$ within each column followed by different letters are significantly different at the $P=0.05$ level. 

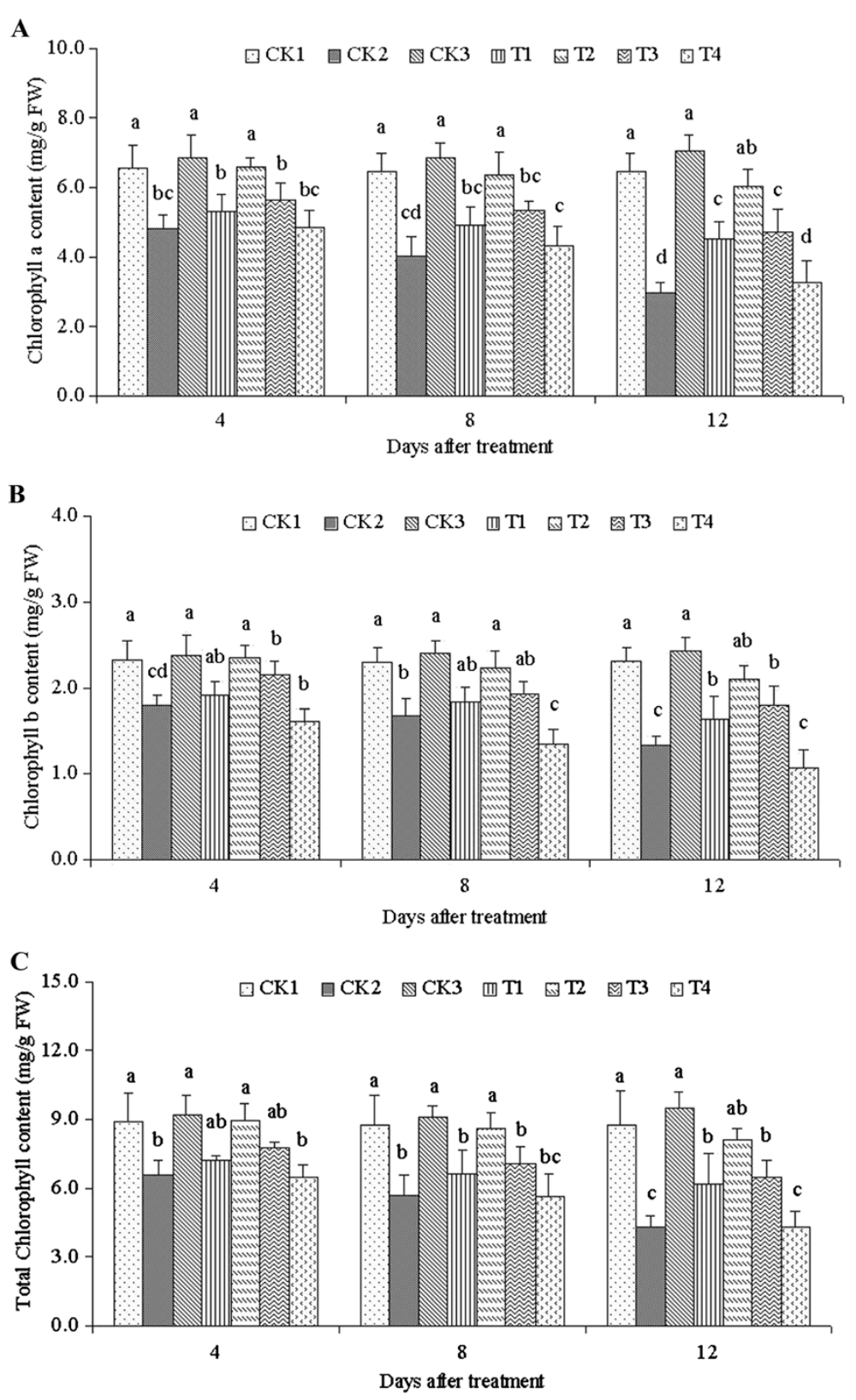

Figure 1 The contents of chlorophyll $a(\mathrm{~A})$, chlorophyll $b(\mathrm{~B})$, and total chlorophyll (C) treated with different ALA concentrations under salinity stress. Vertical bars indicate standard errors $(n=9)$. Mean values with different letters are significantly different by the Tukey test at the $P=0.05$ level.

compared with CK1 and CK3 (25 mg. $\mathrm{L}^{-1}$ ALA only), and the level increased with treatment days (Figure 2A-2D). However, after treatment with different ALA concentrations, these fluorescence parameters improved to various extents, and the differences were significant compared with CK2. The ALA concentration of $25 \mathrm{mg} \cdot \mathrm{L}^{-1}$ at $4 \mathrm{~d}$ had the most significant effect and yielded the maximum values of $0.843\left(F_{\mathrm{v}} / F_{\mathrm{m}}\right), 0.692\left(F_{\mathrm{v}}{ }^{\prime} / F_{\mathrm{m}}{ }^{\prime}\right), 0.872(q P)$ and 0.586 (ФPSII). The change in the non-photochemical quenching (NPQ) was contrary; it increased with the 100 mmol. $\mathrm{L}^{-1} \mathrm{NaCl}(\mathrm{CK} 2)$ treatment and decreased with different ALA concentrations (Figure 2E). The ALA concentration of $100 \mathrm{mg} \cdot \mathrm{L}^{-1}$ had the opposite effect to the other parameters. Hence, the optimum ALA concentration was the relatively low $25 \mathrm{mg} / \mathrm{L}$.

\section{Membrane permeability}

The level of membrane permeability was represented by the relative conductivity. Figure 3A shows that the relative conductivity of the seedlings treated with only $\mathrm{NaCl}$ 


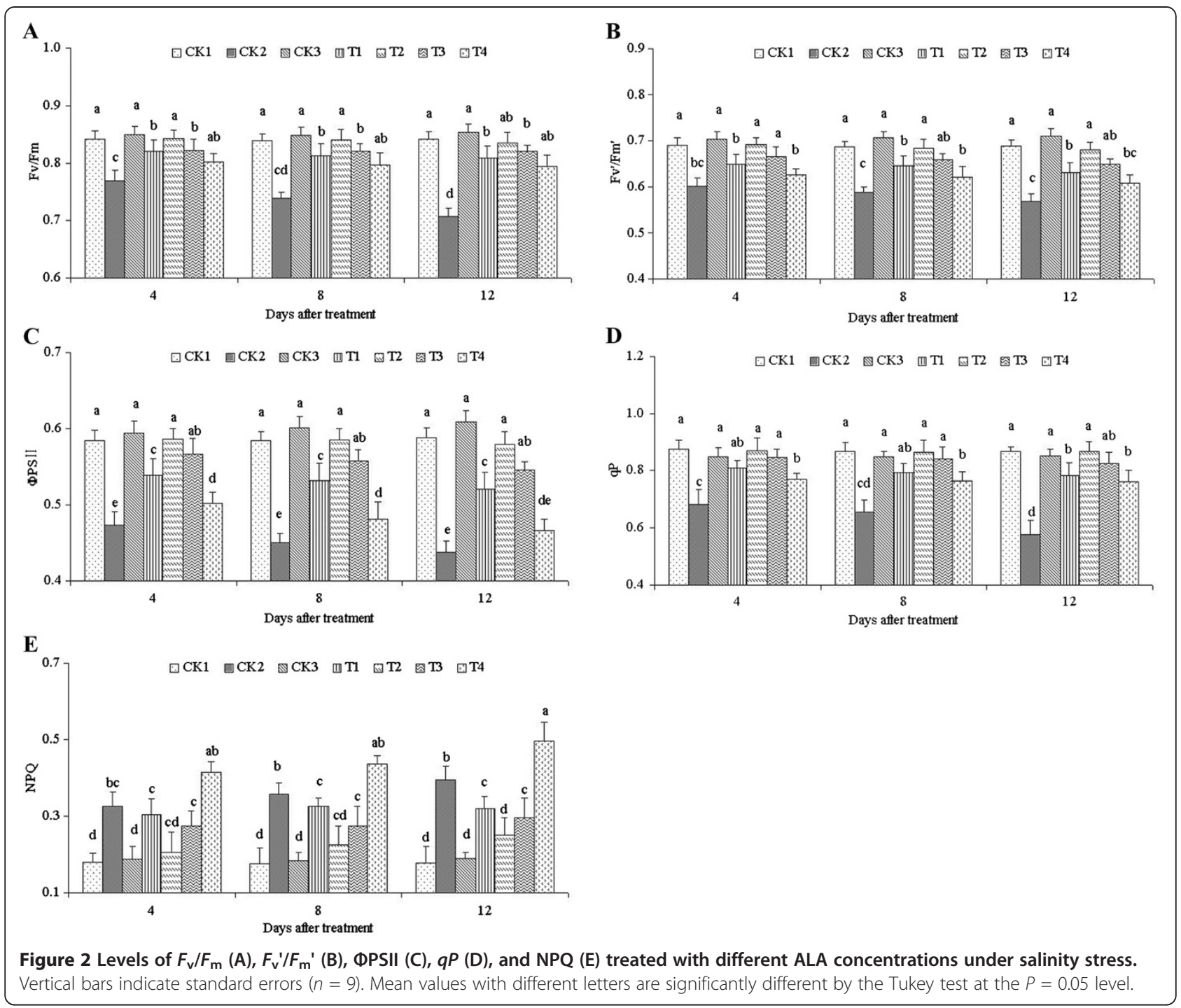

stress (CK2) significantly increased compared with that of the seedlings not treated with $\mathrm{NaCl}$ (CK1 and CK3). The maximum value of $18.17 \%$, which was 5.31 times that of CK1 (3.42\%), was reached $12 \mathrm{~d}$ later. However, the relative conductivity decreased with different ALA concentrations, and reached the minimum of $5.13 \%$ in the $25 \mathrm{mg} \cdot \mathrm{L}^{-1}$ ALA treatment (T2) at $4 \mathrm{~d}$. Treatment with ALA did not significantly differ from the control CK1. These results indicated that salinity stress resulted in the significantly increased membrane permeability of leaves. ALA treatment inhibited the increase in membrane permeability, and effectively decreased the salt stress on the cell plasma membrane damage.

\section{MDA}

The results for lipid peroxidation, estimated as MDA content, are presented in Figure 3B. MDA content increased with treatment days under $\mathrm{NaCl}$ stress, and reached the maximum value on the 12th day with only $100 \mathrm{mmol} \cdot \mathrm{L}^{-1} \mathrm{NaCl}(\mathrm{CK} 2)$. The content significantly decreased with different ALA concentrations (T1-T4), and yielded the minimum value on the fourth day after treatment with $25 \mathrm{mg} \cdot \mathrm{L}^{-1}$ ALA. All ALA treatments (T1-T4) had significant differences compared with the no ALA treatment (CK2).

\section{Total soluble sugars, free proline and soluble protein}

The contents of total soluble sugars, soluble protein, and free proline under $\mathrm{NaCl}$ stress (CK2) all significantly increased compared with CK1 and CK3 (Figure 4). All contents increased in various degree after ALA treatment. All maximum values were reached at $12 \mathrm{~d}$ after $25 \mathrm{mg} \cdot \mathrm{L}^{-1}$ ALA treatment. The soluble sugars and free proline content treated with different concentrations of ALA was similarly and the contents were all increased after the treatment (Figure 4A and 4B). The soluble protein content 

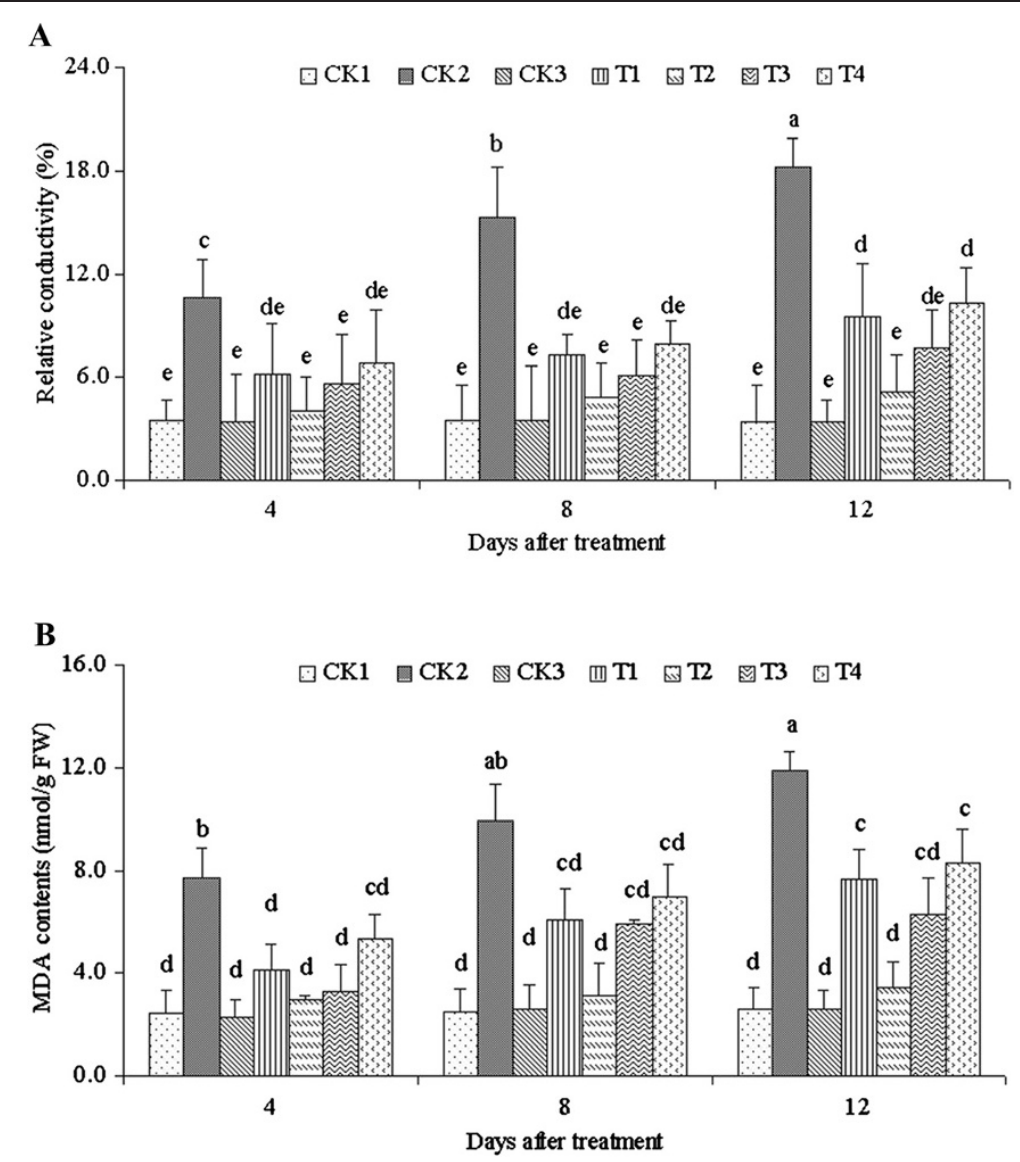

Figure 3 Level of relative conductivity (A) and content of TBARS (B) treated with different ALA concentrations under salinity stress. Vertical bars indicate standard errors $(n=9)$. Mean values with different letters are significantly different by the Tukey test at the $P=0.05$ level.

significantly decreased after the $\mathrm{NaCl}$ only treatment (CK2), and yielded the minimum value (Figure 4C). However, the soluble protein improved with different ALA concentrations, and reached the maximum value on the 12th day after treatment with $25 \mathrm{mg} \cdot \mathrm{L}^{-1}$ ALA.

\section{Activities of three antioxidant enzymes}

To investigate further the action of ALA on salinity stress in C. obtusifolia plants, antioxidant enzyme activities were determined. The activities of SOD, POD, and CAT in response to ALA treatment under a $100 \mathrm{mmol} \cdot \mathrm{L}^{-1} \mathrm{NaCl}$ condition are shown in Figure 5. The activities of CAT, SOD, and POD increased after salinity stress (CK2, treated with only $\mathrm{NaCl}$ and no ALA) compared with the control CK1 (no treatment) and the control CK3 (25 mg.L $\mathrm{L}^{-1}$ ALA and no $\mathrm{NaCl}$ ). This result showed the obvious response of seedlings to stress. SOD activities treated with different ALA concentrations (T1-T4) significantly increased compared with CK1 and CK2 (Figure 5A). Over time, the activities of SOD initially increased, and then decreased. The maximum appeared $8 \mathrm{~d}$ after treatment. The activities under the treatments of $10,25,50$, and $100 \mathrm{mg} \cdot \mathrm{L}^{-1}$ ALA were strongly enhanced by 3.05-, 4.04-, 3.52-, and 2.70fold respectively, compared with CK1 on the 8th day under a $100 \mathrm{mmol} \cdot \mathrm{L}^{-1} \mathrm{NaCl}$ condition, as well as by $1.29-$, 1.71-, 1.49-, and 1.14-fold, respectively, compared with CK2. These results showed that different ALA concentrations improved the activity of SOD, and that the effect of $25 \mathrm{mg} \cdot \mathrm{L}^{-1}$ ALA was the most significant. POD and CAT activities were similar with SOD and reached the maximum with $25 \mathrm{mg} \cdot \mathrm{L}^{-1}$ ALA $8 \mathrm{~d}$ after treatment. The activities of POD and CAT were 138.11 and $122.04 \mathrm{U} \cdot \mathrm{mg}^{-1} \cdot \mathrm{min}^{-1}$, respectively. The various ALA treatments had significant differences from CK1 and CK2 (Figure 5B and 5C). However, the activities did not significantly differ at days 4,8 , and 12 after treatment. This finding indicated that the effect of ALA could be sustained for a long time under salinity stress.

\section{Discussion}

Salinity is one of the most important abiotic stresses that affect crop productivity. Unlike drought, salinity stress is an intricate phenomenon that includes osmotic stress, specific ion effect, nutrient deficiency, etc. Consequently, 

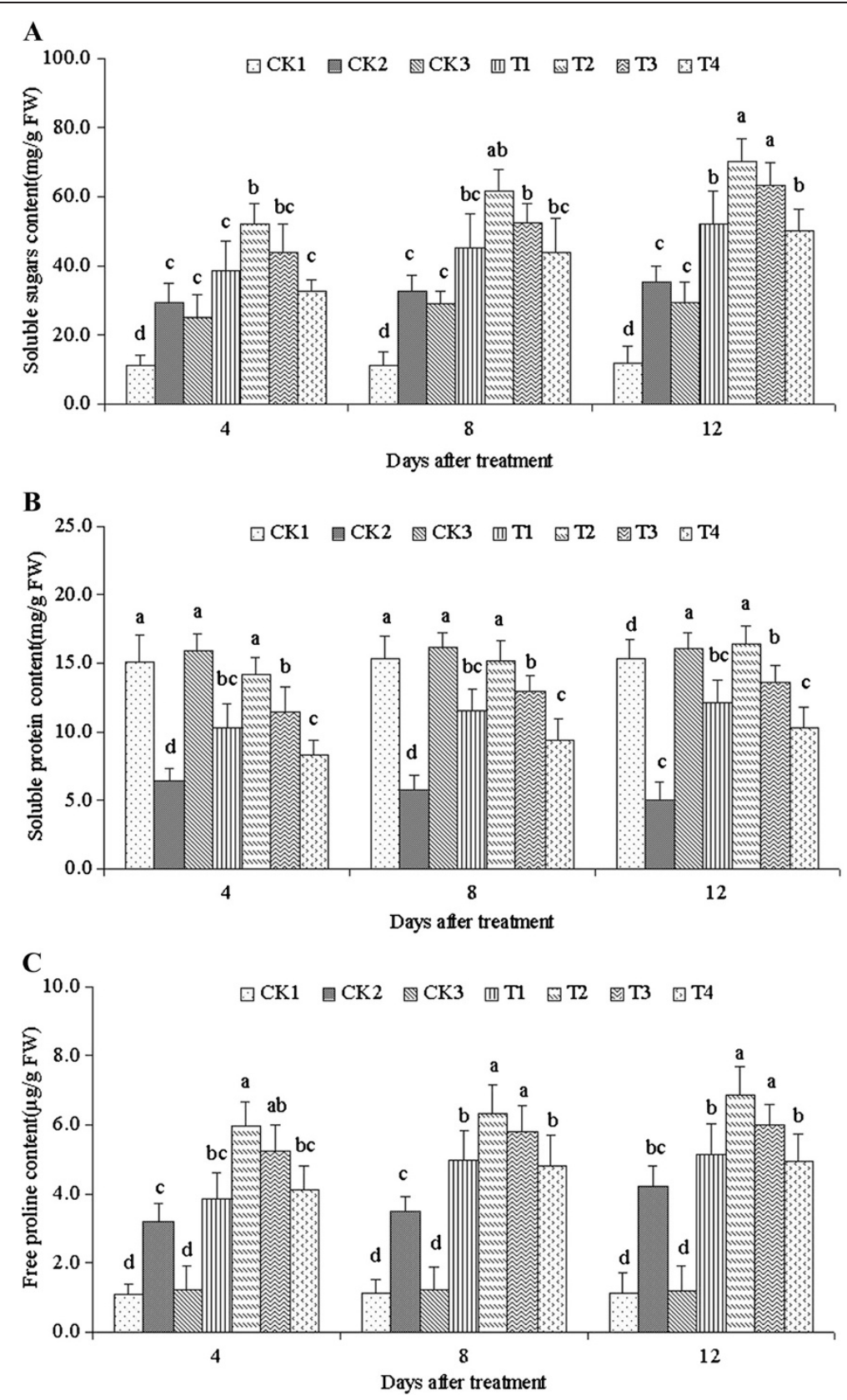

Figure 4 Contents of soluble sugars (A), soluble protein (B), and free proline (C) treated with different ALA concentrations under salinity stress. Vertical bars indicate standard errors $(n=9)$. Mean values with different letters are significantly different by the Tukey test at the $P=0.05$ level.

salinity stress affects various physiological and biochemical mechanisms associated with plant growth and development. Plants have developed various combating mechanisms to cope with the deleterious effects of this stress.

Seed germination is a major stage in the life history of plant. It directly affects plant growth, development, and morphogenesis, as well as indirectly affects yield. Therefore, a seed that is able to germinate quickly is the foundation of high and stable yield. In the current study, the levels of GV, GR, GI, and VI of C. obtusifolia seeds were effectively improved by exogenous ALA application. The results showed that ALA improved the germination and emergence of $C$. obtusifolia seeds under salinity stress. ALA may have imbibed into the seeds during priming and imparted tolerance to salinity stress during seed germination and emergence. 

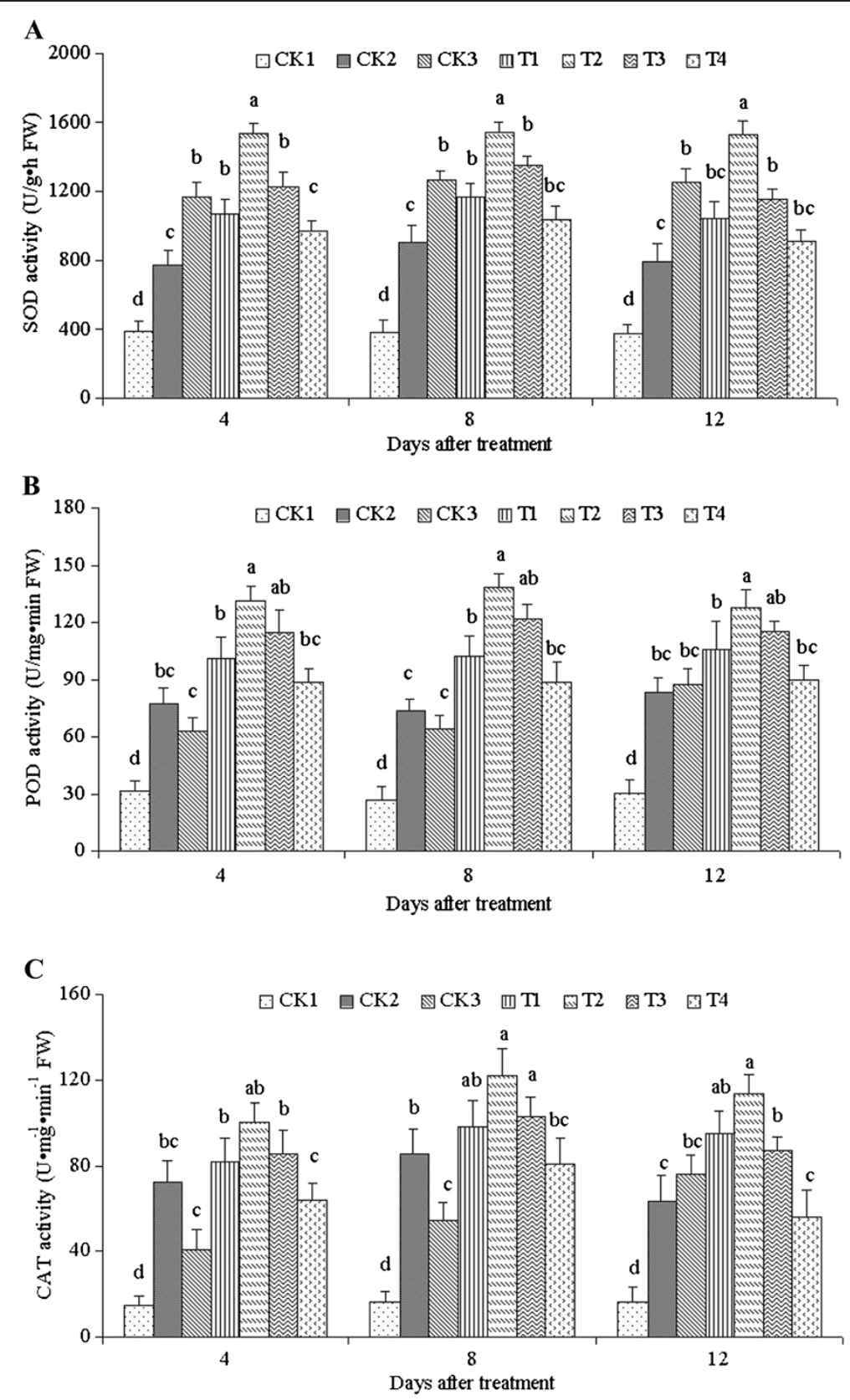

Figure 5 Activities of SOD (A), POD (B), and CAT (C) treated with different ALA concentrations under salinity stress. Vertical bars indicate standard errors $(n=9)$. Mean values with different letters are significantly different by the Tukey test at the $P=0.05$ level.

Hence, ALA treatment could increase the germination ability of $C$. obtusifolia seeds under $\mathrm{NaCl}$ stress.

Previous studies have shown that Chl can be bleached under oxidative stress (Noriega et al. 2004). These results can be explained in two ways. On one hand, ALA at low concentrations acts as a regulator of $\mathrm{Chl}$ and heme biosynthesis. On the other hand, oxidative stress may occur as a result of ROS generated by higher ALA concentrations. ALA, is the key precursor in the biosynthesis of all porphyrin compounds such as Chl and heme. ALA formation in plants is the rate-limiting step in tetrapyrrole biosynthesis (Von Wettstein et al. 1995). In the current paper, the Chl content of C. obtusifolia leaves greatly decreased after salinity stress, signifying that salinity stress injured the synthesis photosynthetic pigments. Treatment with low exogenous ALA concentrations ( $25 \mathrm{mg} / \mathrm{L})$ enhanced Chl content compared with non-ALA-treated plants under salinity stress. Hence, the exogenous appli- 
cation of low-concentration ALA prior to salinity stress is a possible method for overcoming an inadequate biosynthesis problem.

Photosynthesis is an important metabolic process in plant and significantly affects plant growth, yield, as well as resistance to adverse environmental factors. Plant photosynthesis is obviously affected by salinity stress. The direct results are photosynthetic system damage, photophosphorylation, and photosynthetic electronic transfer. The indirect results are those involving enzymes in dark reactions. Consequently, photosynthesis can be used as a significant index for evaluating plant growth and tolerance. Chl fluorescence measurements have recently been used to estimate rapidly and noninvasively the operating quantum efficiency of electron transport via PSII in plant leaves (Baker and Rosenqvist $2004)$. The photochemical efficiency of PSII $\left(F_{\mathrm{v}} / F_{\mathrm{m}}\right)$ is proportional to the potential maximal quantum yield of PSII (Hormann et al. 1994), $F_{\mathrm{v}} / F_{\mathrm{m}}$ is the efficiency of the primary conversion of the light energy of PSII, which indicates the ability of PSII light energy utilization and is closely related to the photoinhibition of the photosynthesis degree (Maxwell and Johnson 2000), $F_{\mathrm{v}} / F_{\mathrm{m}}$ is also called the optimal photochemical efficiency of PSII in the dark. $F_{\mathrm{v}}{ }^{\prime} / F_{\mathrm{m}}{ }^{\prime}$ represents the light energy conversion efficiency of the open PSII center, which is called the effective photochemical efficiency or antenna pigment transformation efficiency of PSII in light (Zhang 1999). $F_{\mathrm{v}} / F_{\mathrm{m}}$ is one of the $\mathrm{Chl}$ fluorescence indices that are usually used in stress conditions. $F_{\mathrm{v}} / F_{\mathrm{m}}$ is decreased under stress, thereby indicating PSII damage $(\mathrm{Xu}$ and Zhang 1999). The actual photochemical efficiency of PSII (ФPSII) reflects the actual original light energycapturing efficiency of the PSII response center under some closed circumstances. In the current paper, Chl fluorescence kinetics indicated that $F_{\mathrm{v}} / F_{\mathrm{m}}, F_{\mathrm{v}}{ }^{\prime} / F_{\mathrm{m}}{ }^{\prime}$, and ФPSII significantly decreased under $\mathrm{NaCl}$ stress. This finding revealed that PSII suffered damage in various degrees. Nevertheless, the light energy capture efficiency significantly improved upon treatment with different ALA concentrations.

The coefficients of photochemical quenching $(q P)$ could reflect the redox state of PSII original electronic receptor QAs and the number of PSII open centers. $q P$ reflects the PSII centers of openness to some extent, and the non-photochemical quenching (NPQ) is the photosynthetic apparatus of self-protective mechanisms (Havaux et al. 1991). The NPQ process is an adaptive mechanism that prevents photoinhibition and membrane damage to plants by adjusting the dissipation of excessive energy. The photosystem, by increasing nonradiative heat dissipation, could consume the excessive light energy absorbed by PSII. Consequently, the PSII response center is protected from damage by photooxidation and photoinhibition for absorbing excess light energy. In the present study, the level of $q P$ declined under $\mathrm{NaCl}$ stress, indicating that $\mathrm{NaCl}$ stress led to decreased openness of PSII reaction centers. The accumulation of reduced electron acceptors may increase the probability of generating reactive radicals, which may further cause injury to PSII components (Barber and Andersson 1992). The light energy captured from the antenna pigment used for photochemical reactions and the photochemical activity of the PSII reaction center both decreased. Consequently, excess light energy accumulated in the PSII reaction center under $\mathrm{NaCl}$ stress. The photosystem was effectively protected by the dissipated excess light energy via the improved level of NPQ. ALA with different concentrations (T1-T4) improved the level of $q P$ and decreased the level of NPQ, showing that the salinity stress-induced damage to C. obtusifolia had been alleviated by ALA. ALA with concentration of $100 \mathrm{mg} \cdot \mathrm{L}^{-1}$ has the opposite effect to NPQ, NPQ improved significantly compared with other concentrations. This result indicated that higher concentration of ALA has significant inhibitory effect to C. obtusifolia seedlings.

Increased MDA content is a good reflection of oxidative damage to membrane lipids as well as other such vital molecules as proteins, DNA, and RNA. In the present study, the TBARS levels significantly increased compared with the controls under salinity stress. The peroxidation of membrane lipids may result in enhanced membrane fluidity, which may lead to enhanced electrolyte leakage and support the hypothesis that salinity stress can induce membrane lipid peroxidation. Salinity treatments caused by significantly increased lipid peroxidation during salt stress have been reported. Higher lipid peroxidation has also been reported in salt stresssensitive rice varieties (Dionisio-Sese and Tobita 1998). Increased lipid peroxidation due to salinity stress results in a significantly increased membrane permeability. The extents of lipid peroxidation and membrane permeability have been used as indices of salt injury and tolerance in Amaranthus (Battacharjee and Mukherjee 1996). Increased membrane permeability has been suggested to reflect the extent of lipid peroxidation caused by ROS (Sairam et al. 1998). In the present study, the TBARS content and membrane permeability increased under $\mathrm{NaCl}$ stress. This result indicated that the membrane was damaged by ROS, cell membrane peroxidation occurred, and the normal physiological function of the plasma membrane became disordered. After treatment with exogenous ALA, TBARS content and membrane permeability significantly decreased. Therefore, ALA alleviated the damage caused by $\mathrm{NaCl}$ stress.

The accumulations of soluble sugars, soluble protein, and free proline under stress protect plant cells by balancing the osmotic strength of cytosol with that of vacuoles 
and the external environment (Gadallah 1999). These solutes are cytosolic osmotic substances, and may also interact with cellular macromolecules such as enzymes to stabilize the structure and function of such macromolecules. A direct consequence of a higher osmolyte concentration is the maintenance of comparatively antioxidant enzyme activities (Smirnoff and Cumbes 1989). The results of the present study indicated that the contents of soluble sugar, soluble protein, and free proline treated with ALA in C. obtusifolia seedling leaves were significantly higher than those treated with $\mathrm{NaCl}$ stress (CK2). A lower osmotic potential within the cell was possibly maintained to help cells absorb water from the external environment, resulting in resistance to the damage caused by $\mathrm{NaCl}$ stress.

To endure oxidative damage under conditions of increased oxidative stress such as salinity, plants must possess efficient antioxidant systems. Plants do possess antioxidant systems in the form of enzymes such as SOD, POD, and CAT; they also have an efficient system for decomposing ROS, using the enzyme SOD in chloroplasts (Asada 1999). SOD is located in chloroplasts, mitochondria, the cytoplasm, and peroxisomes. SOD serves as the first line of defense against ROS (Liau et al. 2007). A high SOD activity can efficiently remove $\mathrm{O}_{2}^{-}$, which leads to the production of $\mathrm{H}_{2} \mathrm{O}_{2} . \mathrm{H}_{2} \mathrm{O}_{2}$ can be scavenged by CAT and GR (glutathione reductase) in the Halliwell-Asada pathway. The accumulation of $\mathrm{H}_{2} \mathrm{O}_{2}$ then begins and exacerbates membrane lipid peroxidation, causing membrane damage. POD could remove SOD disproportionation products and synergizes with SOD, the essential condition of a salt-resistance mechanism. Protective enzymes increase to a high level to remove ROS and keep them at a low level. Consequently, the function and structure of undamaged membranes are maintained. In the current paper, three kinds of antioxidant enzymes significantly increased with different ALA concentrations, although the change trends are slightly different. Apparently, the three enzymes had different strategies for facing stress. Exogenous ALA treatment improved the abilities of the three enzymes for resisting peroxide damage to plant cells.

So far, the reason for ALA-induced increase in antioxidant enzyme activity in plants is still unknown. It may be related to the conversion of ALA into heme, as suggested by a previous study that exogenous ALA processing promotes heme efflux from intact developing cucumber chloroplasts and translates it into hemoglobin (Thoms and Weinstein 1990). ${ }^{14} \mathrm{C}$ has also been found to permeate into the porphyrin auxiliary molecules of peroxidase and pigment cells upon treatment with ${ }^{14}$ C-ALA (Van Huyestee 1977). Evidently, heme is an auxiliary component of peroxidase, and ALA treatment promotes the synthesis of heme (Hunter et al.
2005). Consequently, peroxidase activity and anti-oxidative stress are increased.

\section{Conclusion}

The present study revealed that ALA with an appropriate concentration could significantly alleviate $\mathrm{NaCl}$ stress-induced damage to C. obtusifolia seeds and seedlings. The alleviation is achieved via improved antioxidant enzyme activities, increased Chl content and photosynthetic efficiency, strengthened capacity of scavenging ROS, increased membrane stability, decreased cell osmotic potential, as well as decreased membrane lipid peroxidation.

\section{Abbreviations}

ALA: 5-Aminolevulinic acid; CAT: Catalase; CHI: Chlorophyll; $F_{\mathrm{v}} / F_{\mathrm{m}}$ : Photochemical efficiency of photosystem $\| ; F_{v}{ }^{\prime} / F_{m}$ : Photochemical efficiency; Gl: Germination index; GR: Germination rate; GV: Germination vigor; NBT: Nitroblue tetrazolium; NPQ: No-photochemical quenching coefficient; POD: Peroxidase;

$q P$ : Photochemical quench coefficient; ROS: Reactive oxygen species; SOD: Superoxide dismutase; TBARS: Thiobarbituric acid reactive species; VI: Vigor index; ФPSII: PSII actual photochemical efficiency.

\section{Competing interests}

The authors declare that they have no competing interests.

\section{Authors' contributions}

C-PZ responsible for seedlings cultivation, tissue culture, sampling and biochemical analysis. F-GY, S-JH and $\mathrm{H}-\mathrm{YL}$ analysed the data presented in this paper. $\mathrm{PH}$ designed the experiment, supply all the instruments analyzed in this study, Y-CL drafted the manuscript. All authors read and approved the final manuscript.

\section{Acknowledgments}

The authors gratefully acknowledge the financial support of the National Natural Science Foundation of China (Grant Nos. 30560025 and 31060069).

\section{Author details}

${ }^{1}$ School of Life Sciences, Southwest University, Key Laboratory (Ministry of Education) of Eco-environments of Three Gorges Reservoir Region, Chongqing Key Laboratory of Plant Ecology and Resources Research for Three Gorges Reservoir Region, Chongqing 400715, PR China. ${ }^{2}$ Department of Biology and Center for Chinese Medicine Research, Hong Kong University of Science and Technology, Hong Kong SAR 999077, PR China. ${ }^{3}$ Laboratory Center, Xuzhou Medical College, Xuzhou 221002, PR China. ${ }^{4}$ School of Forestry, Southwest Forestry University, Kunming, 650224, PR China.

Received: 24 October 2011 Accepted: 16 November 2012 Published: 23 August 2013

\section{References}

Ahmad S, Wahid A, Rasul E, Wahid A (2005) Comparative morphological and physiological responses of green gram genotypes to salinity applied at different growth stages. Bot Bull Acad Sin 46:135-142

Anu SJ, Rao JM (2001) Oxanthrone esters from the aerial parts of Cassia kleinii. Phytochemistry 57:583-585

Asada K (1999) The water-cycle in chloroplasts: scavenging the active oxygens and dissipation of excess photons. Annu Rev Plant Biol 50:601-639

Baker NR, Rosenqvist E (2004) Application of chlorophyll fluorescence can improve crop production strategies: an examination of future possibilities. J Exp Bot 55:1607-1621

Barber J, Andersson B (1992) Too much of a good thing: light can be bad for photosynthesis. Trends Biochem Sci 17:61-66

Bates LS, Waldran RP, Teare ID (1973) Raipid determination of free proline for water studies. Plant Soil 39:205-208 
Battacharjee S, Mukherjee AK (1996) Ethylene evolution and membrane lipid peroxidation as indicators of salt injury in leaf tissues of Amaranthus seedlings. Indian J Exp Biol 34:279-281

Chakrabory N, Tripathy BC (1992) Involvement of singlet oxygen in 5aminolevulinic acid induced photodynamic damage of cucumber chloroplast. Plant Physiol 98:7-11

Demmig-Adams B, Adams WWIII, Barker DH (1996) Using chlorophyll fluorescence to assess the fraction of absorbed light allocated to thermal dissipation of excess excitation. Physiol Plant 98:253-264

Dionisio-Sese ML, Tobita S (1998) Antioxidant responses of rice seedlings to salinity stress. Plant Sci Limerick 135:1-9

Eiji N, Kensuke K, Mohammad MP (2003) Role of 5-aminolevulinic acid (ALA) on active oxygen-scavenging system in $\mathrm{NaCl}$-treated spinach (Spinacia oleracea). J Plant Physiol 160:1085-1091

Gadallah MAA (1999) Effect of proline and glycine betaine on Vicia faba responses to salt stress. Biol Plant 42:247-249

Genty B, Briantais JM, Baker NR (1989) The relationship between the quantum yield of photosynthetic electron transport and quenching of chlorophyll fluorescence. Biochem Biophys Act 99:87-92

Goel A, Sheoran IS (2003) Lipid peroxidation and peroxide-scavenging enzyme in cotton seeds under natural ageing. Biol Plant 46:429-434

Havaux M, Strasser RJ, Greppin H (1991) Atheoretical and experimental analysis of the $q P$ and $q N$ coefficients of chlorophyll fluorescence quenching and their relation to photochemical land non photochemical event. Photosynth Res 27:41-55

Heath RL, Packer I (1968) Photoperoxidation in isolated chloroplst I, kinetics and stochiometry of fatty acid peroxidation. Arch Biochem Biophys 125:189-198

Hormann H, Neubauer C, Schreiber U (1994) On the relationship between chlorophyll fluorescence quenching and the quantum yield of electron transport in isolated thylakoids. Photosynth Res 40:93-106

Hotta Y, Tanaka H, Takaoka Y, Takeuchi Y, Konnai M (1997a) Promotive effects of 5 -aminolevulinic acid on the yield of several crops. Plant Growth Regul 22:109-114

Hotta Y, Watanabe K, Tanaka T, Takeuchi Y, Konnai M (1997b) Effects of 5aminolevulinic acid on growth of plant seedlings. J Pest Sci 22:102-107

Hunter AG, Rivera E, Ferrreira GC (2005) Supraphysiological concentrations of 5-aminolevulinic acid dimerize in solution to produce superoxide radical anions via a protonated dihydropyrazine intermediate. Arch Biochem Biophy 437:128-137

Joshi H, Kapoor VP (2003) Cassia grandis Linn. f. seed galactomannan: structural and crystallographical studies. Carbohydrate Res 338:1907-1912

Kalpana R, Madhava Rao KV (1995) On the aging mechanism in pigeonpea (Cajanus cajan L.) seed. Seed Sci. Technol 23:1-9

Korkmaz A (2005) Inclusion of acetyl salicylic acid and methyl jasmonate into the priming solution improves low temperature germination and emergence of sweet pepper seeds. HortSci 40:197-200

Kumar AM, Chaturvedi S, Söll D (1999) Selective inhibition of HEMA gene expression by photooxidation in Arabidopsis thaliana. Phytochemistry 51:847-851

Li Y, Qu JJ, Yang XM, An LZ (2008) A report on ultra-dry storage experiment of Zygophyllum xanthoxylon seeds. Bot Stud 49:243-251

Liau YJ, Wen L, Shaw JF, Lin CT (2007) A highly stable cambialisticsuperoxidedismutase from Antrodia camphorata: expression in yeast and enzyme properties. J Biotechnol 131:84-91

Lichtenthaler HK (1987) Chlorophylls and carotenoids: pigments of photosynthetic biomemranes. Methods Enzymol 148:350-382

Lowry OH, Rosebrough NJ, Farr AL, Randall RJ (1951) Protein measurement with the Folin phenol reagent. J Biol Chem 193:265-275

Maxwell K, Johnson GN (2000) Chlorophyll fluorescence-a practical guide. J Exp Bot 51:659-668

McDonald MB (1999) Seed deterioration: Physiology, repair and assessment. Seed Sci Technol 27:177-237

Nishihara E, Kondo K, Parvez MM, Takahashi K, Watanabe K, Tanaka K (2003) Role of 5-aminolevulinic acid (ALA) on active oxygen-scavenging system in $\mathrm{NaCl}$ treated spinach (Spinacia oleracea). J Plant Physiol 160:1085-1091

Noriega GO, Balestrasse KB, Batlle A, Tomaro ML (2004) Heme oxygenase exerts a protective role against oxidative stress in soybean leaves. Biochem Biophys Res Commun 323:1003-1008

Sairam RK (1994) Effect of moisture stress on physiological activities of two contrasting wheat genotypes. Indian J Exp Biol 32:584-593
Sairam RK, Desmukh PS, Saxena DC (1998) Role of antioxidant systems in wheat genotypes tolerant to water stress. Biol Plant 41:387-394

Sayed OH (2003) Chlorophyll fluorescence as a tool in cereal research. Photosynthetica 41:321-330

Smirnoff N, Cumbes QT (1989) Hydroxyl radicals scavenging activity of compatible isolates. Phytochemisiry 28:1057-1060

Stobart AK, Ameen-Bukhari J (1984) Regulation of $\delta$-aminolevulinic acid synthesis and protochlorophyllide regeneration in the leaves of dark-grown barley (Hordeum vulgare) seedlings. Biochem 222:419-426

Storey R, Wyn-Jones RG (1975) Betaine and choline levels in plnats and their relationship to $\mathrm{NaCl}$ stress. Plant Sci Lett 4:161-168

Thoms J, Weinstein JD (1990) Measurement of heme efflux and heme content in isolated developing chloroplasts. Plant Phy 94:1414-1423

Van Huyestee RB (1977) Porphyrin and peroxidase synthesis in cultured peanut cells. Can J Bot 55:1340-1344

Von Wettstein D, Gough S, Kananagara C (1995) Chlorophyll biosynthesis. Plant Cell 7:1039-1105

Wahid A, Parveen M, Gelani S, Basra SMA (2007) Pretreatment of seeds with $\mathrm{H}_{2} \mathrm{O}_{2}$ improves salt tolerance of wheat seedling by alleviation of oxidative damage and expression of stress proteins. J Plant Physiol 164:283-294

Wang LJ, Jiang WB, Zhang Z, Yao QH, Matsui H, Ohara H (2003) 5-Aminolevinilic acid and its potential application in agriculture. Plant Physiol Commun 39:185-192

Xu CC, Zhang JH (1999) Effect of drought on chlorophyll fluorescence and xanthophyll cycle components in winter wheat leaves with different ages. Acta Phytophysiologica Sinica 25:29-37

Xu PL, Guo YK, Bai JG, Shang L, Wang XJ (2008) Effects of long-term chilling on ultrastructure and antioxidant activity in leaves of two cucumber cultivars under low light. Physiol Plant 132:467-478

Yemm EW, Willis AJ (1954) The estimation of carbohydrates in plant extracts by anthrone. Biochem J 57:508-514

Zhang CP, He P, Du DD, Wei PX, Yu ZL, Xie YZ, Liu HY (2011) Effect of exogenous Nitric Oxide donor SNP on seed germination and antioxidase activities of Perilla frutescens seedlings under $\mathrm{NaCl}$ stress. JChinese Med Materials 34:3114-3119

Zhang CP, He P, Du DD, Yu ZL, Hu SJ (2010) Effect of zinc sulphate and PEG priming on ageing seed germ ination and antioxidase activities of Perilla frutescens seedlings. China J Chinese Materia Medica 35:2372-2377

Zhang SR (1999) A discussion on chlorophyll fluorescence kinetics parameters and their significance. Chinese Bulletin of Botany 16:444-448

Zhang ZJ, Li HZ, Zhou WJ, Takeuchi Y, Yoneyama K (2006) Effect of 5aminolevulinic acid on development and salt tolerance of potato (Solanumtuberosum L.) microtubers in vitro. Plant Growth Regul 49:27-34

\section{doi:10.1186/1999-3110-54-18}

Cite this article as: Zhang et al:: Role of 5-aminolevulinic acid in the salinity stress response of the seeds and seedlings of the medicinal plant Cassia obtusifolia L.. Botanical Studies 2013 54:18.

\section{Submit your manuscript to a SpringerOpen ${ }^{\circ}$ journal and benefit from:}

- Convenient online submission

- Rigorous peer review

- Immediate publication on acceptance

- Open access: articles freely available online

- High visibility within the field

- Retaining the copyright to your article

Submit your next manuscript at springeropen.com 